\begin{tabular}{l} 
RCCS \\
\hline Annual Review
\end{tabular}

\section{RCCS Annual Review}

A selection from the Portuguese journal Revista Crítica de Ciências Sociais

5 | 2013

Issue no. 5

\title{
Investigating Homelessness: In Defence of a Declared and Concerned Ontological Politics
}

\author{
João Aldeia
}

Translator. Sheena Caldwell

\section{OpenEdition}

\section{Journals}

Electronic version

URL: http://journals.openedition.org/rccsar/483

DOI: $10.4000 /$ rccsar.483

ISSN: $1647-3175$

\section{Publisher}

Centro de Estudos Sociais da Universidade de Coimbra

\section{Electronic reference}

João Aldeia, «Investigating Homelessness: In Defence of a Declared and Concerned Ontological

Politics », RCCS Annual Review [Online], 5 | 2013, Online since 01 October 2013, connection on 19 April 2019. URL : http://journals.openedition.org/rccsar/483 ; DOI : 10.4000/rccsar.483 
João Aldeia

School of Economics, University of Coimbra, Portugal

\title{
Investigating Homelessness: In Defence of a Declared and Concerned Ontological Politics*
}

\begin{abstract}
Quantification and pathological individualization are the two dominant trends within homelessness research. In acquiring near-exclusive status in this research, they constitute a regime of truth and produce a series of unsustainable negations: they deny that they produce the realities which they study, they deny that other realities may be produced, they delegitimise any alternative methodological positionings, and render power relationships and domination invisible, thus obscuring the injustice of life on the streets. As an alternative to this regime of truth, this article argues for the mobilisation of a declared ontological politics that is concerned with the welfare and dignity of homeless people.
\end{abstract}

Keywords: homelessness; ontological politics; power; regime of truth; research methodology.

\section{Introduction}

There is a dominant regime of truth in homelessness research. It is composed of two separate but complementary aspects, namely the tendency towards quantification and pathological individualization of the phenomenon. This regime of truth, like any other, constitutes the materialisation of certain realities produced by the research process itself, which can only be accomplished at the cost of actively rendering alternative realities invisible (Foucault, 1978, 1991; Mol, 2002; Foucault, 2003; Law, 2004; Santos, 2006, 2007). However, the main problem of this dominant position is not the fact that it creates absences: they are an integral part of the methodological process of making sense of the world. What does prove problematic is (1) the process by which invisibilities are transformed into negations, with the result that all realities not present in the dominant methodological practice are viewed as impossibilities, thus reducing the field of possibilities to what is made to exist; and (2) the fact that the particular absences created by this regime of truth are essential to understanding homelessness as something characterised, above all else, by injustice and extreme domination. By emphasising the "major statistical trends" of the phenomenon, this regime produces a superficial view of homelessness that prevents access to the plurality of ways of thinking and acting that characterise it, leaving out of the produced reality actors, spaces and interactions that are vital to the study of life on the streets. Assigning individual

\footnotetext{
* Article published in RCCS 97 (June 2012).

I would like to thank Silvia Portugal for her careful reading of the various versions of this text and for her suggestions, and Teresa Tavares for her help with the translation of the article. All the problems that remain, however, are entirely my responsibility.
} 
causes to a phenomenon that occurs for structural reasons helps naturalise - and, in extremis, deny - problems in the housing and labour markets and in state and institutional actions in the "welfare" sector, thus providing support for a particular way of blaming the "victims" for their situation.

Concern for the wellbeing and dignity of those who are homeless does not allow researchers to be complicit in the reproduction and reinforcement of this regime of truth. It is essential to carry out an exercise in ontological politics (Mol, 2002; Law, 2004) which allows another reality of the phenomenon of homelessness to be produced ${ }^{1}$ : an ontological politics that recognises the multiplicity, complexity and fluidity of its different features and does so by emphasising the concern to improve the living conditions of homeless actors. However, we also need an ontological politics that explicitly defines itself as such and that, unlike the prevailing regime of truth, which denies making choices about what it makes present and absent, explains the reasons why certain presences are preferable to others, as well as openly acknowledging the fact that it creates absences. This exercise should function on two complementary time frames. The first involves the initial step towards a concerned and declared ontological politics: a rejection of rendering invisible the domination and injustice that characterize homelessness. Since it is only by taking injustice and domination into account that it is possible to combat them, the second political ontological moment is concerned, by necessity, with the collective production of a more just reality, which does not include people living on the streets.

I will begin by reflecting on the dominant regime of truth in what concerns the two dimensions referred to above. My main argument is not that these research positions correspond to incorrect perspectives, since this would have to be based on the idea that

\footnotetext{
${ }^{1}$ In the sense of enactment, which should be distinguished from construction. Both concepts refer to the idea that the objects and realities studied are brought into existence by the methodological practices deployed to study them and that there is no reality external to these practices. However, the concept of construction supposes that these methodological practices stabilise gradually and also stabilise the objects/realities which they study - produce. Bearing in mind that the denial that they produce the realities being studied is an integral part of the very practices that produce them, the concept of construction is based on the idea that the realities being studied and the practices used to study them may gain sufficiently general acceptance for one of the multiple practices and one of the possible multiple realities to acquire the appearance of exclusivity. The idea that these practices may be altered, thus changing the reality that has been made to exist, is not ignored, but the cost of such alterations is emphasised. The concept of enactment rejects this possibility of unique stabilisation. It acknowledges that there may be stabilisations, but these will always be multiple, depending on the various practices deployed in each space-time. Thus, enactment has a performative dimension: the realities which practices make present only remain present while the practices are executed. On the notion of enactment, see Mol (2002) and Law (2004).
} 
there is a reality of homelessness that is exterior to the methodological practices deployed to study it. I do not believe that such an exterior reality exists, and therefore the issue in question is not one of perspective. ${ }^{2}$ It extends further than this: quantification and pathological individualization, rather than perspectives, are the wrong methods ${ }^{3}$ for studying and producing a phenomenon characterised by domination and injustice. They make present parts of the reality of the phenomenon that do not contribute towards understanding or solving it (the use of drugs and alcohol and mental illness), and render absent the fundamental realities of life on the streets (the labour market and housing, the role of the state, the survival strategies of those who live on the streets, disrespect, stigmatisation, social disqualification and poverty). As an alternative, I defend a methodological position that explicitly acknowledges itself as a process that produces reality, that creates presences and absences, that states the reasons why certain presences are more desirable or necessary than others, that clarifies what it makes invisible, and does all this on the basis of a concern

\footnotetext{
${ }^{2}$ Throughout the text, the fundamental epistemological distinction between perspectivism and constructivism will be deployed, introducing into the discussion the idea of ontological politics, understood as a particular type of constructivism. In broad terms, I understand perspectivism to be a methodological position that conceives of the reality being studied as something external to the methodological process of supplying meaning for the world. Hence, methodology is not a matter of "producing" but "discovering" a reality, and the different ways of describing and analysing it are conditioned by the different positions which the subjects occupy in the world, leading to separate "views" of the same reality, which is therefore approached from different standpoints. In this way, the possibility of "agreement between perspectives," in the sense of approaching the correct reality, is something contemplated by perspectivism. Constructivism, on the other hand, rejects the unity of the real, affirming that the actual differentiated positioning of the subjects creates different realities. As this is not a solipsistic position, this construction of reality is a collective exercise, carried out by relational networks rather than isolated individuals (no isolated element in the network has total control over the reality they all produce), from which different phenomena result which, in discursive terms, are often given the same name. Ontological politics emerges as a way of clarifying certain constructivist premises. Firstly, it accentuates the relational nature of the production of reality, contesting certain constructivist lines which, whilst taking interaction as a tacit starting assumption, do not make this explicit, thus creating confusion between "constructivism" and "solipsism." In making ontological politics the centre of the methodological procedure, we are forced to accept that realities exist outside individual perceptions, yet there are no realities outside the meanings that are constructed by a relational network. In addition, a methodology that makes its political ontological nature explicit reveals a possible dimension of intentionality in the production of realities: if these are performed by interactionally linked individuals, it is then plausible that, collectively, they may strive to enact them in a politically or morally desirable way.

${ }^{3}$ It becomes essential to deploy a broad concept of method. In doing so, it becomes clear that any methodological position has a political dimension. The methodological choices we make are far from reducible to the different techniques for producing information, and even less reducible to taking a position on the "quantitative/qualitative" dichotomy. Taking the notion of ontological politics as its base, a moral positioning concerned with the welfare and dignity of the actors whose lives are being studied obliges the researcher to contribute towards improving their living conditions through the work $\mathrm{s} / \mathrm{he}$ is doing, which should enable a better world to be produced, namely by revealing the relational inequalities that reduce certain individuals' life possibilities. I understand "wrong" methods to be all those which, conversely, contribute in some way towards reproducing a status quo in the distribution of power that continues to hurt actors already being hurt in the studied phenomena.
} 
that results from the indignation felt by the researcher in the face of the oppression and injustice that characterise homelessness.

\section{"How many homeless are there (and who are they)?"}

There is no consensual definition of homelessness in space or time or amongst institutions and researchers. ${ }^{4}$ The only thing that all the definitions seem to have in common is the fact that they are based on what lacks to the individuals who live on the streets: the lack of housing, social ties, money, physical and/or mental health, etc. Not only does a consensual definition not exist, but more than this, it cannot exist, given that the homeless do not constitute a "separate category" from the rest of society but are part of a continuum of precariousness - in housing, to a large extent - together with the domiciled population. The "homeless" category only exists to the extent that it is created by the methodological practices deployed by researchers, by professionals who work with subjects living on the streets and by policymakers who work on the phenomenon.

These actors consider the conceptual range of the definition to be an essential issue. It wavers between very restricted definitions - to be "homeless" stricto sensu, literally sleeping on the street or in some other "public" space not destined for this purpose - and other very broad definitions, in which being "homeless" becomes linked to and confused with many other situations of precariousness and vulnerability, in particular housing vulnerability (Jacobs, Kemeny and Manzi, 1999; Brousse, 2005; Gaboriau and Terrolle, 2009).

Definitions with different ranges will always produce different figures for the number of individuals living on the streets. In general, non-government institutions use broader definitions and state institutions more restricted ones, duly resulting in larger or smaller "homeless populations." This difference also originates - in a complementary way - from the way in which the "homeless" are counted. From a statistical point of view, it is possible to "measure" this "population" as stock - considering the number of subjects that correspond to a given definition of "homeless" at a particular point in time - or as flow - taking the number of individuals that correspond to a given definition of "homeless" over a period of

\footnotetext{
${ }^{4}$ There are various discussions regarding definitions of homeless(ness). Brousse (2005), Jacobs, Kemeny and Manzi (1999) and Damon (2008: 2-7, 129-148) consider it necessary to define a population, despite identifying various problems in the process. The qualitative positions of Hopper (1997), Rullac (2012), Zeneidi-Henry (2002: 16-50) and, in particular, Gaboriau (2004) and Gaboriau and Terrolle (2009) appear more interesting, being characterised by rejections of a definition, which they consider unnecessary for a conception of homelessness that emphasises its procedural links with other situations of structural poverty and domination.
} 
time (for instance, one year). ${ }^{5}$ Governments usually prefer to "measure the homeless population" as stock, given that the figures are always lower than those for flow, and institutions that do not depend directly on the government in general opt for measurements of flow. NGOs that work with homeless people have a clear interest in justifying their existence and institutional continuity and therefore need funding. Using a broad definition of "homeless" to support measurement by flow will provide figures that are always much higher than those measured by stock based on a more restricted definition. If the available (produced) statistical data allow us to state that "there are many homeless individuals," it will then be necessary to preserve the institutions that work with them. Conversely, it is in the interest of governments to publicly present a relatively low number of homeless individuals in order to downplay the problem. Moreover, measurement by flow will always show a higher number of individuals who are "temporarily" homeless, i.e. who do not live on the streets for long periods of time, whereas measurement by stock will overrepresent the number of "the chronic homeless," i.e. those who have been homeless for several years.

The multiple forms of calculation make quantification problematic, to say the least, if not impossible. However, additional issues relating to practical difficulties should also be mentioned. The fact that various homeless individuals cannot be visually identified as such (Gaboriau, 2004: 115-116; Damon, 2008: 3; Gaboriau and Terrolle, 2009; Rullac, 2012) or the difficulty in gaining access to many of the sleeping places that these individuals choose for reasons of privacy and protection - often in spaces where people may walk past without realising that a human being is sleeping just a few metres away (Pichon, 1996, 2002; Gaboriau, 2004: 115-116) - make it difficult to accept that it is possible to obtain representative figures for the "homeless population." The possibility of carrying out a survey in collaboration with the "welfare" institutions that work with people living on the streets would not help in obtaining data that could be interpreted as representative either - at least, not representative of the population which the study intends to cover. Several homeless individuals shun contact with these institutions and will not eat or spend the night in them (Snow and Anderson, 1993; Pichon, 1996, 2002; Gaboriau, 2004; Damon, 2008: 228-229;

\footnotetext{
${ }^{5}$ On issues regarding methods for calculating the "homeless" population, see Brousse (2005) for a view which, whilst identifying their problems, defends the usefulness of quantification. See Gaboriau (2004) for a firm rejection of the quantitative position. Between total rejection of quantification (Gaboriau) and the search for solutions to the problems of calculation (Brousse), Damon (2008: 129-148) stands closer to the latter than the former position. Hopper (1997) and Zeneidi-Henry (2002: 38-42) are further removed from Brousse, defending qualitative methodologies but without the fierce criticisms of quantification levelled by Gaboriau.
} 
Rullac, 2012; Gowan, 2010). They cannot therefore be found in institutional facilities and, in the case of various subjects, no institution can say where they sleep at night. These individuals will not figure in any statistical survey said to be "representative of the homeless population," regardless of the method chosen to gather the data. In the final analysis, institutional contact does not serve to define any "homeless population," but only to create a conceptual distinction (whether intentional or not) between "those with secure housing" and "individuals who are users of services."

It is impossible for researchers to safeguard themselves from these questions by resorting to a "representative" sample procedure which allows them to ignore individuals who are impossible to contact. Given that it is not possible to count these subjects, we cannot know how many they are, and therefore how can we work on the basis that they are residual for a statistical survey of this population?

In short, the only populations about whom quantitative data can be produced are the "identifiable homeless" on the streets or in institutions (regardless of the definition used) and the "users of services" (Gaboriau, 2004; Gaboriau and Terrolle, 2009). However, studies referring to homeless individuals that are repeatedly taken to be "representative" of this population have thus the perverse characteristic of actually referring to another population. As Gaboriau and Terrolle state,

In short, the survey is feasible. It has already been done. It will be done today with the guarantee of competent statisticians and experts. It will allow for substantial funding. It will provide the illusion of the quantifiable and the "known" - if "quantity" is better defined, we feel we are in control of the situation. This apparent rigour will serve as an alibi for some cause or another. But it will provide a figure that does not correspond to the population of homeless people. (2009: 15)

These problems mean that there are no reliable statistics for homelessness (Blau, 1992: 15-30; Hopper, 1997; Gaboriau, 2004; Zeneidi-Henry, 2002: 38-49; Damon, 2008: 139-144). Given the enormous difficulties regarding quantification, the validity of any future statistics produced on the problem may also be questioned. Even if the data produced were reliable, would it help us to understand the living conditions of people on the streets? Given that data reliability is low or non-existent and that, even if this were not the case, a quantification of the number of people living on the streets would not serve to understand how they live, it is reasonable to state that "the number of these homeless people does not help us to understand them better or to perceive the reality of their bond to society" (Guibert-Lassalle, 
2006: 46). This being the case, we should view any figures for the number of homeless individuals - whether officially, institutionally or academically produced - with less than full confidence, regardless of the definitions or statistical procedures used. ${ }^{6}$ The only thing we know for certain about the phenomenon is that there are too many individuals living on the streets. We do not know this because there are 500 of them, or 5,000 , but because, as Machado Pais states, "it does not matter to me how many [homeless individuals] there are even one would be too many" (2006: 38).

More than being important to studying the phenomenon, defining what being "homeless" means is vital for its statistical quantification, since these calculations serve to support political measures. The way in which people are defined as "homeless" is a power mechanism that classifies particular individuals in a particular social position, reinforcing a position of structural domination (Gaboriau, 2004: 113-115). In other words, as previously stated, the methodological practice of defining a "homeless population" is a means of creating the "homeless" as a category. This category will always be disqualified in various ways - not least because it is based on what subjects lack - and it will be on this basis that the institutions working with homeless individuals will find justification for intervening over those who live on the streets in a way that denies their capacity to act and think. There are therefore political aspects to the definition of "homeless" that must be considered (Hopper, 1997; Zeneidi-Henry, 2002: 16-50; Gaboriau, 2004; Damon, 2008: 2-7, 129-148; Rullac, 2012). Through this categorisation, homeless individuals are generally represented as a "homogeneous group," denying the huge diversity of situations, behaviours, biographies and worldviews of people who live on the streets. This homogenisation facilitates the development of public policies, given that they tend to be viewed as having a "single object." Since the actual empirical heterogeneity of homelessness is ignored, these policies will target an abstract subject produced as real, rather than concrete individuals. Thus, this political treatment of the phenomenon will always result in a mismatch between the policy targets and the subjects to which they are applied.

As stated at the beginning of this section, there is a total continuity between situations of domination, poverty and precariousness (whether housing-related or other) experienced by

\footnotetext{
${ }^{6}$ As an example, it is with this reduced degree of certainty that we should view the data which tells us that there were 1,377 homeless individuals, in the restricted sense, in Portugal in 2007-2008 (data not "statistically representative" of the country, but gathered in Lisbon in 2007 and in Coimbra and Amadora in 2008) (Edgar, 2009: 74).
} 
actors "with" and "without" homes. If there is no straightforward divide between "with" and "without a home," then it is not possible to define and statistically calculate a "homeless population" (Gaboriau, 2004; Gaboriau and Terrolle, 2009). Thus, a definition of homelessness is of little sociological use. Failing to define it does not make it difficult to study; on the contrary, it revalues the empirical, which comes to be seen as the only valid source for determining whether the individuals with whom the researcher interacts may or may not be considered "homeless." Any definition, whether broader or more restricted, will always be an exercise in dichotomous compartmentalisation of reality and this should be avoided: it is precisely by looking at the interaction between those "with" and "without a home" that it is possible to produce sociologically relevant work.

In addition, a definition based on "what these subjects lack" has the immediate effect of obscuring "what they have." This may not be much, and it may even be devastating in its scarcity - ever-present in their daily lives - but it does not mean that we should ignore what they have: representations of the world and of themselves, desires, knowledges, capacities, values, feelings. The question posed by Gaboriau and Terrolle is imperative: "Couldn't we talk about the wretched in some other way, in terms of what they think, with their outlook on life and on our society?" (2007: 29). Homelessness research has to look both at what individuals lack and what they possess; it has to recognise the voice of those who live in the misery which is life on the streets without ignoring the fact that this misery is real and limiting. Academic-scientific discourse on the phenomenon has to be constructed with those who live on the streets and take into account how they see their situation.

\section{Pathological individualization}

The pathological individualization of homelessness features as the other dominant methodological stance, which very often supplements quantification. There are two idealtypical registers for pathological individualization: (1) one derived from the medical model; and (2) another referring to the "amorality" of homeless subjects, represented as actors who reject the domiciled normativity of the rest of society. In socio-historical terms, the latter prevailed up to the early $20^{\text {th }}$ century, emphasising that homeless individuals were to blame for their situation and focusing on their "amorality, laziness and (possible) dangerousness." During the period of strong state regulation and relative economic prosperity that followed the Second World War, the structural dimensions of poverty began to be emphasised, and 
attention was paid to the factors that led certain groups and subjects into dominated situations (Castel, 1996, 2003; Gowan, 2010).

Since the 1980s the medical model has gradually established itself as the guiding force behind the definitions, representations and actions of domiciled society to address homelessness and people who live on the street. It is now the official position of "welfare" institutions and prevails in academic-scientific research. This model conceives of the phenomenon as a series of individual cases, viewing the fact that people live on the streets as a symptom of individual disturbances or disorders (Blau, 1992; Lyon-Callo, 2008; Gowan, 2010). It is therefore a perspective that argues that what is needed is to identify and treat individual problems. Medically, "homelessness [is] neither the result of criminality nor social injustice [...] but a symptom - of addiction, mental frailties, post-traumatic stress syndrome and other sicknesses" (Gowan, 2010: xviii). Thus the ideal-typical medical model distances itself from the "(a)moralising" register but contributes as much as the latter towards actively rendering invisible the systemic aspects of homelessness (Gowan, 2010).

For Conrad,

medicalization consists of defining a problem in medical terms, using medical language to describe a problem, adopting a medical framework to understand a problem, or using a medical intervention to "treat" it. This is a sociocultural process that may or may not involve the medical profession, lead to medical social control or medical treatment, or be the result of intentional expansion by the medical profession. Medicalization occurs when a medical frame or definition has been applied to understand or manage a problem. (1992: 211)

It is therefore a process by which a particular phenomenon comes to be understood and managed in accordance with an analytical framework derived from the medical model. Whilst the medical profession does not necessarily have to be involved in the process, its presence reinforces the domination of medicalization as a means of observing and dealing with the phenomenon. Three separate but complementary levels of medicalization can be identified: i) a conceptual level, in which a medical vocabulary is deployed to frame the phenomenon; ii) an institutional level, in which the organisations involved use a medical approach to deal with a specific problem within their area of expertise; iii) and an interactional level, in which the direct doctor-patient relationship is present and in which the former defines and (medically) treats an individual problem that may or may not be social in origin (and therefore, in empirical terms, not a pathology of the subject-patient). It is only on this third level that the medical profession is always involved (ibidem: 211). 
The involvement of the medical profession is not a conditio sine qua non for the medicalization of a phenomenon. In recent decades, the medical model has been extended to various aspects of society, and several professions not directly linked to medicine have begun using a medicalizing discourse. The capacity to "medically" define behaviours and people - for Conrad (1992), the main indicator of the power of the medical model - is present in various research studies on homelessness originating in psychology and social work, among others, which use medical frameworks to approach the problem and see the identification of individual pathologies in each homeless person as their principal concern. The main objective of such studies is to discover - define, produce - the "mental illness" or alcohol and/or drug addiction that prevents a particular homeless individual from getting off the streets and "integrating" into domiciled society. In this register, the solution for getting off the streets (not for ending homelessness, but for each individual exit) lies in the personal conversion of the individual, in his/her adaptation to a society which, although it may be seen as unjust, is above all naturalised (Blau, 1992; Lyon-Callo, 2008; Gowan, 2010). The individualization of causes and solutions for homelessness renders invisible the structural factors that make certain subjects "homeless," and thus homelessness comes to be seen as a "symptom of the severe mental illness and substance abuse of the few and [as having] little to do with working and housing conditions for the many" (Gowan, 2010: 50). As a consequence of the dominance of the medical model, the category of the "mentally ill and deviant homeless" is created and homogenised; it is a category that is "separate from the rest of society" and whose existence is not due to the way in which society is organised, but rather to individual factors that differentiate "homeless" subjects from those who are “domiciled" (Blau, 1992; Lyon-Callo, 2008; Gowan, 2010).

In rejecting the medical model as a means of constructing knowledge on homelessness, it should be borne in mind that

systemic inequities contribute to the production of many behaviors that are commonly read as pathological disorders among people without permanent shelter. Reading these behaviors as individual disorders certainly plays a role in silencing work against exploitative social conditions and in limiting our ability to work more effectively against the condition that [this] work documents. (Lyon-Callo, 2008: 52)

Various behaviours on the part of homeless individuals which are taken to be indicators of "pathologies" are more or less efficient ways of dealing with the harshness of life on the streets. However, "with the medicalization of social problems, it becomes common sense to 
understand the coping strategies of homeless people as symptoms and evidence of mental illness" (ibidem: 53). Amongst other things, the "medicalization" of certain behaviours turns the "homeless" into the "passive victims" of pathologies, denying them the capacity to act and reflect on the world and on themselves, socially and morally justifying that they should be biopolitically managed by "welfare" and repressive institutions.

The medical model and the "(a)moralising" register are ideal types. In praxis - including the praxis of production of academic-scientific knowledge - the two models combine, creating an archetype of the "homeless" individual that is characterized simultaneously by "mental illness, drug addiction, alcoholism, laziness, amorality and criminality"; therefore, this individual must be taught to "integrate" into society. In practice, the medical model is not axiologically neutral but, on the contrary, incorporates moral considerations, leading to the complementarity of "repressive" and "welfare" practices and discourses (Feldman, 2006; Lyon-Callo, 2008; Gowan, 2010). The dominant research trend is therefore not reduced to the ideal-typical medical model but refers to pathological individualization in general, whether this occurs under the register of "mental illness" or "sociocultural deviance," or even (as is more common) a combination of both.

Pathological individualization combines with quantification, with the latter contributing a great deal to the former. Given that, as seen in the previous section, there are more "homeless" when the population is measured as flow rather than as a stock, and that calculating them according to the latter restricts the population to a group of subjects who have been on the streets for a long time - and therefore can be supposed to be more adapted to these living conditions - a restricted definition that supports quantification by stock facilitates the "pathologisation" of the phenomenon (Wright and Rubin, 1998: 41-46; O'Sullivan, 2008: 74). This facilitation of "pathologisation" results from the absence of a longitudinal view of measurements by stock, which can also lead to confusion between the causes of homelessness (i.e. the reasons why subjects end up on the streets) and the effects of life on the street which, at most, may be causes for the persistence of homelessness (i.e. the reasons why subjects remain on the streets). This confusion may lead to psychological, drug and alcohol problems being interpreted as the causes of the phenomenon when in reality they may be derived from the situation of living on the streets, and may therefore be factors that partly explain why certain individuals remain homeless (Blau, 1992: 17; Phelan and Link apud O'Sullivan, 2008: 74). Some methods of statistical production distort the 
phenomenon more than others, facilitating pathological individualization, but all statistical production has a distorting effect. As Blau states, "social science research [...] consistently turns demographic characteristics into causes of homelessness" (1992: 17).

\section{A declared and concerned ontological politics}

As with any other method, quantification and pathological individualization produce specific realities; each of these methods constructs a particular kind of homelessness, mobilising specific practices, discourses, actors and materialities and does so by studying concrete spatial-temporal contexts. Like any other method, quantification and pathological individualization make parts of homelessness present, and do so at the cost of rendering other parts invisible (Law, 2004). In conceiving of the issue in this way, the problem of quantification and pathological individualization is not that they are wrong perspectives. The argument of this text aims to extend beyond perspectivism, considering that quantification and pathological individualization are wrong methods, incapable of producing realities that take into account the enormous power differences and structural domination that characterize homelessness.

We are not facing a problem of perspective since, if we were, we would have to believe that there is one essentialist reality of homelessness that can be discovered through the correct use of certain methodologies. This is not the case. This phenomenon, like any other, is produced by the methodological practice itself (Mol, 2002; Law, 2004). The problem with quantification and pathological individualization is the fact that, whilst being as selective about the realities they produce as any other method, they do not acknowledge this. The reality of homelessness they produce is brought into existence at the cost of annulling alternative realities. It constitutes a regime of truth (Foucault, 1978, 1991, 2003), a particular representation of the possibilities of reality. It is a regime of truth that is as much discursive as material - discourse is, in itself, materiality but, pursuing Foucault's reflections based on the ideas of Law (2004), Mol (2002) and Latour (1987), a regime of truth is also constituted by things, objects, and the physical practices of subjects. The regime of truth constituted by the combination of quantification and pathological individualization has to be deconstructed since, given its dominant character, it denies that other realities of homelessness exist or may exist. The statements which these methods make about the phenomenon acquire the status of (quasi) exclusivity, and are thus uncritically accepted by the media, politicians, 
ordinary citizens and the sections of academia that dominate research in this area. New statements will be produced based on them, supported by a spiralling process that, as it advances, has the effect of increasingly hiding the choices which these methods make, in particular the realities of the phenomenon which are repeatedly made invisible ${ }^{7}-$ public policies that are incapable of ensuring a dignified standard of living for those who live on the streets, deregulation of the housing and labour markets, the capacity of homeless actors to act and reflect, the unofficial interactions in which they are involved, the multiple survival strategies they are forced to develop in the face of the failure of the state and the market, etc. ${ }^{8}$ As Law (2004) and Latour (1987) argue, a fundamental part of the process of knowledge production - of reality production - is its retrospective annulment. Its production context is, to a great extent, negated by its justification context (Feyerabend, 1993).

Since the reality of homelessness is produced by the methodological practices we mobilise to understand it, the truth about this reality is also produced by these practices and is not, therefore, a criterion for knowledge validation (Foucault, 1978, 1991; Mol, 2002; Foucault, 2003; Law, 2004). It could only be so if there was only one reality of homelessness, exterior to the practices of knowledge production, passive, coherent with itself, and able to be discovered through the use of various methods. If this were the case, we could argue that one perspective on it would be better than another and seek the appropriate method for accessing this reality. However, we are not in this kind of situation. Homelessness is characterised above all by its fractionality (Mol, 2002; Law, 2004). It is multiple - composed of the failures in the labour and housing markets, failures of the state, the subjectivities and survival strategies of those who live on the streets, the set of institutional disciplinary and "welfare" measures, the discourses about it, and all the other factors that may be included in a discussion of the subject. Yet it is multiple without being plural, it is more than one without being various: all the different realities of homelessness that we can identify, that we can produce, are linked. They combine, coordinate and cooperate in complex ways, contributing

\footnotetext{
${ }^{7}$ On the process of producing statements in scientific practice in general, see Latour (1987) and Law (2004).

${ }^{8}$ However, the statements of those who defend this regime of truth do not go unquestioned, and various authors, although still a minority within academia, have contested them. The work of Gaboriau and Terrolle (Gaboriau, 2004; Gaboriau and Terrolle, 2007, 2009), Lyon-Callo (2008), Gowan (2010), Hopper (1997, 2003) and Bourgois and Schonberg (2009) are exercises in the deconstruction of quantification and individualized "pathologisation," by making visible the structural and interactional dimensions of homelessness which the dominant regime of truth renders invisible. These authors, in different ways, use ethnographic approaches to produce alternative realities of homelessness, emphasising the domination and injustice that are present in the lives of homeless actors. Despite the heterogeneity of their work, it is possible to find a common positioning on homelessness, one which I share.
} 
to constructing one reality of homelessness with an apparent singularity, and this is achieved by reducing what may exist to what is actively made to exist, turning the realities produced by quantification and pathological individualization into a single reality with the status of exclusivity and denying the existence and legitimacy of the alternative realities that are made invisible in the process.

It is useless to study homelessness if we do not feel outraged by the fact that there are people living on the streets, who are oppressed, hungry, cold, treated without respect, without dignity. To study homelessness is useless if we do not feel revolted when we see these people's capacity to act denied as they are constructed (reified) as "mentally ill," or when we see them in possession of a purely negative action when they are constructed (reified) as "criminal and idle." It is this reality of domination and injustice that should be studied. In order to do so, we need different methods from those which have acquired the status of near-exclusivity. We need a broader understanding of method - a method assemblage (Law, 2004) - that allows us to make present the injustice of life on the streets, the institutionally produced elements of domination, the suffering felt by concrete bodies, the indignation of homeless actors over this, and the panoply of power relations that can be observed in the interactions in which they are involved. This exercise should be carried out openly and must assume a concern for a better world, a desire for the elimination of the enormous power differences that disqualify those who live on the streets, and a recognition that the only way to do this is to eliminate the existence of people living on the streets. We need a methodological positioning that explicitly places the researcher in the field and acknowledges his/her influence over the research and its influence over him/her. We need a methodological approach which assumes that the researcher considers that there are some realities of homelessness that are more important to produce than others, given that not all can be present simultaneously (Law, 2004). However, this being the case, this declared commitment to the construction of a particular reality through the mobilised methodological practice also implies that the realities that are deliberately made absent are made explicit. This does not mean that all of them should be made explicit in the same way - multiplicity would make this impossible - but that we should, at least, clarify that we are producing absences during the research process, that we are aware of doing so and that we want to do 
so - to make present the structural dimensions of the phenomenon, to openly make absent the "mental illness" of homeless actors, to make implicitly absent other realities. ${ }^{9}$

If it is not the search for truth but the production of reality(ies) that directs methodological practice, then methodology is a political problem par excellence. Method is the means of producing the realities that we, as a society, are interested in producing. It therefore becomes necessary to acknowledge this aspect of method in studying homelessness or any other subject. Investigating the world is an exercise in ontological politics (Mol, 2002; Law, 2004), an exercise in the production of realities: "a politics that has to do with the way in which problems are framed, bodies are shaped and lives are pushed and pulled into one shape or another" (Mol, 2002: viii). It is, however, necessary to make this selection explicit and to seek to develop methodologies that enable fluid, complex and sometimes incoherent realities to be produced, rejecting the exclusivity of any particular reality, specifically the one that is currently dominant. Ontological politics is an integral part of any method: it is through it that we make the choice about which realities are made present and which are made absent. However, quantification and pathological individualization are exercises in a covert ontological politics which does not acknowledge in fact, rejects - its nature as an ontological politics. They produce knowledge and realities but in the same process they deny that they do so. They choose the reality they produce, at the same time choosing the knowledge about it that is made present, whilst denying that they do so. They locate the realities they produce outside their own methodological practices, denying that they influence them whilst producing knowledge about them. In this way, they reduce discussion of homelessness to questions of perspective: they argue that the reality is the same but the perspectives on it are different. However, if "the reality is the same," given that quantification and pathological individualization present themselves as the accepted "correct" methods, their "perspective" on this reality, which is exterior to the practices, cannot fail to be correct. ${ }^{10}$ If the "perspective" is "the correct one," then it must also be exclusive, given that the alternative "perspectives" must be "wrong." This negation for the sake of methodological domination is unsustainable, and what is rendered invisible by these presences is too important to remain absent. Feyerabend's (1993) logic must be

\footnotetext{
${ }^{9}$ See Law (2004) for a broader discussion of the relationship between "presence," "manifest absence" and "absence as Otherness" (implicit).

${ }^{10}$ Or at least, it could come to be, given that certain "minor" imprecisions are recognised in the practical application of the method.
} 
recognized as fundamental in methodological practice: "anything goes," provided that it is justified. Any reality that is produced is legitimate, provided that the fact that we are producing it and the way in which we do so are duly explained. However, whilst it may be legitimate to produce all realities, not all of them are desirable. It is here that ontological politics becomes particularly relevant. Opting for the reality that does not conceal domination or the one that makes those living on the streets responsible for living on the streets are substantially different choices, and a researcher who is concerned with human dignity cannot be complicit in the production of the latter.

If quantification and pathological individualization are not the path(s) to follow, this is, to a large extent, due to the profoundly decontextualized nature of the statements they make. The knowledge they produce is related to a particular context - a particular reality - but the part of the process that leads to the annihilation of its own influence on the production of reality conceals the space-time of this reality. It turns that which is local knowledge (which all knowledge is) $)^{11}$ into "universal" knowledge. A reality produced in a specific way in a concrete space-time thus becomes the reality, not only for this time and space but for many others as well.

One of the main problems of the dominant regime of truth is this "universal" nature. To a large extent it is by denying its parochialism that the reality it produces may be presented as singular and exterior. It is only possible to fight against this if contextual research into homelessness makes its contextualisation explicit. In the positivist model of knowledge, universalism is seen as the prime objective of information produced by research. Yet this can only be achieved by the process of obscuring research practices, an integral part of which is the negation of the context in which they occur. A declared and concerned ontological politics can only exist to the extent that it is relative to specific situations. These cannot be made invisible; they are a fundamental part of the reality which the method seeks to make present.

This research positioning regarding homelessness cannot be affirmed as "universal." It is not "generalizable" in the positivist sense - which should be translated as "decontextualized." Instead, a concerned and declared ontological politics must function through a praxiography (Mol, 2002) of a specific context, an ethnography of the practices of a

\footnotetext{
${ }^{11}$ See Law (2004), Latour (1987) and Flyvbjerg (2011) on the local and contextual nature of all knowledge produced.
} 
particular space-time. ${ }^{12}$ The concern with the injustice resulting from major power imbalances which amount to domination can only be transformed into a part of what we produce as present if the research field is approached intensively over a prolonged period. ${ }^{13}$ The subjectivities of the actors, the resources they deploy to confront domination and survive, the discourses which homeless subjects incorporate, readapt, rearticulate, produce and circulate, their relations in areas outside the public eye, in short, a substantial part of the set of practices that make up the phenomenon cannot be observed when the realities we want to produce do not include them. They cannot be observed when what we are looking for are the superficial "main trends" of the phenomenon, the identification (production) of problems in terms of existing clinical frameworks or the dominant representations of the "amoral" character of the "undeserving poor." Homelessness understood as domination requires an approach to what lies beyond what is immediately visible when we look at life on the streets. When the interest lies in making unjust power relations present, we also have to look at what is taking place in the "backstages" (Goffman, 1959) of social life, in the hidden transcripts (Scott, 1985, 1990) of dominated actors. ${ }^{14}$ Looking at these realities does not allow us to look at others. Once again, what is important is to make explicit that the reality that a clear and concerned ontological politics wants to produce is that of the relational production of power, not as an end in itself, but as part of a wider ontological politics. As previously stated, all realities are equally legitimate but not all are equally desirable. Making present the reality of the relational production of power in homelessness is desirable to the extent that it is perceived as unjust and degrading. The political exercise includes fighting this reality. Yet it is only by producing it as present in all its complexity - the first step in a declared and concerned ontological politics - that it is possible to fight it and seek to create

\footnotetext{
12 Since Nels Anderson (1965; Anderson and Rauty 1998), the first "classic" reference in homelessness research in academia, it is clear that this phenomenon has to be the subject of contextualised and prolonged ethnographic study.

${ }^{13}$ The recent ethnographies by Gowan (2010) and Bourgois and Schonberg (2009), curiously both carried out in San Francisco, offer excellent examples of the possibility of studying homelessness in ways which criticise the dominant regime of truth, proposing the construction of alternative realities for life on the streets, and emphasising the enormous power differences and structural and interactional injustices in the lives of homeless actors. Whilst it is possible to disagree with the particular positions taken by the authors, both works are exemplary not only for the profound knowledge they reveal of the realities studied but also for their committed stance towards fighting this domination and injustice and the fact that they explicitly assume the position of authors in the field.

${ }^{14}$ In this respect the good example of research provided by Bourgois and Schonberg (2009) should be noted. Their photo-ethnography of homeless addicts in San Francisco is an interesting exercise in studying what takes place precisely in social spaces of difficult access for researchers.
} 
another, more just, reality that does not include people living on the streets - the second political ontological step.

\section{A conclusion...}

... must be rejected, given that the process is open and ongoing. The methodological positioning defended here does not aim to present itself as "the path" for research to follow, but one possible path. The details of contextual findings can only be approached and resolved contextually. Providing "universal" methodological guidelines for approaching specific fields of research is nonsensical and counterproductive. It hinders good research. We need rules, but contextual rules, adapted to the occasion (Feyerabend, 1993; Law, 2004; Flyvbjerg, 2011). What validates the sharing of the knowledge we produce is not the fact of using the same procedures in different space-times but the explicitness of the different ways of doing what we do. This is the main problem with the dominant regime of truth in homelessness research. It produces too many negations, reduces the scope of the possible to what already exists, so that it no longer makes sense to think of a better (different) world than the one that already exists, given that this becomes the best (only) world possible. It negates the research context through pretensions to "universalism" and does not acknowledge parts of this context due to methodological standardisation. It denies that it produces reality(ies), that it produces presences and invisibilities. It denies that it is possible to produce alternative realities using alternative methods. The dominant regime of truth rejects its political ontological nature. The only defensible general rule is that of explicitness: "anything goes," but we have to be aware of what we are doing and account for how we do it. This will vary according to the context being investigated but, in the particular case of homelessness, it cannot make injustice and domination invisible. Rejecting the methodological domination of the regime of truth discussed is the first step towards approaching and fighting the praxiological domination (which must be) present in homelessness.

Translated by Sheena Caldwell

Revised by the author and Teresa Tavares 


\section{References}

Anderson, Nels (1965), The Hobo. The Sociology of the Homeless Man. Chicago \& London: University of Chicago Press [orig. ed.: 1923].

Anderson, Nels; Rauty, Raffaele (eds.) (1998), On Hobos and Homelessness. Chicago \& London: University of Chicago Press.

Blau, Joel (1992), The Visible Poor: Homelessness in the United States. New York \& Oxford: Oxford University Press.

Bourgois, Philippe; Schonberg, Jeff (2009), Righteous Dopefiend. Berkeley, Los Angeles, London: University of California Press.

Brousse, Cécile (2005), "Définir et compter les sans-abri en Europe: enjeux et controverses," Genèses, 58, 48-71.

Castel, Robert (1996), "Les marginaux dans I'histoire," in Serge Paugam (ed.), L'exclusion, l'état des savoirs. Paris: La Découverte, 32-41.

Castel, Robert (2003), From Manual Workers to Wage Laborers. Transformation of the Social Question. New Brunswick \& London: Transaction Publishers [orig. ed.: 1995].

Conrad, Peter (1992), "Medicalization and Social Control," Annual Review of Sociology, 18: 209-232.

Damon, Julien (2008), La question SDF: critique d'une action publique. Paris: PUF [orig. ed.: 2002].

Edgar, Bill (2009), European Review of Statistiques on Homelessness in Europe. Brussels: FEANTSA.

Feldman, Leonard C. (2006), Citizens Without Shelter: Homelessness, Democracy, and Political Exclusion. Ithaca \& London: Cornell University Press [orig. ed.: 2004].

Feyerabend, Paul K. (1993), Against Method. London \& New York: Verso Books [orig. ed.: 1975].

Flyvbjerg, Bent (2011), Making Social Science Matter: Why Social Inquiry Fails and How It Can Succeed Again. Cambridge: Cambridge University Press [orig. ed.: 2001].

Foucault, Michel (1991), "Truth and Power," in Paul Rabinow (ed.), The Foucault Reader: An Introduction to Foucault's Thought. London: Penguin, 51-75 [orig. ed.: 1977].

Foucault, Michel (1978), The History of Sexuality. Volume I: An Introduction. New York: Pantheon Books [orig. ed.: 1976].

Foucault, Michel (2003), "17 March 1976", in Michel Foucault, "Society Must Be Defended." Lectures at the Collège de France, 1975-76. New York: Picador, 239-264 [orig. ed.: 1997].

Gaboriau, Patrick (2004), "Mettre les questions à la question. Travail de terrain et raisonnement sur les 'sans-logis'," Espaces et sociétés, 116-117(1-2): 111-123.

Gaboriau, Patrick; Terrolle, Daniel (2007), SDF: critique du prêt-à-penser. Toulouse: Privat.

Gaboriau, Patrick; Terrolle, Daniel (2009), "L'étude des personnes sans logis," in Patrick Gaboriau \& Daniel Terrolle (eds.), Ethnologie des sans-logis: étude d'une forme de domination sociale. Paris: L'Harmattan, 5-18 [orig. ed.: 2002].

Goffman, Erving (1959), The Presentation of Self in Everyday Life. Garden City, New York: Doubleday, Anchor Books [orig. ed.: 1956].

Gowan, Teresa (2010), Hobos, Hustlers, and Backsliders: Homeless in San Francisco. Minneapolis \& London: University of Minnesota Press.

Guibert-Lassalle, Anne (2006), “Identités des SDF," Études, 405 (7-8): 45-55. 
Hopper, Kim (1997), "Homelessness Old and New: The Matter of Definition," in Dennis P. Culhane \& Steven P. Hornburg (eds.), Understanding Homelessness: New Policy and Research Perspectives. Washington: Fannie Mae Foundation, 9-67 [orig. ed.: 1991].

Hopper, Kim (2003), Reckoning with Homelessness. Ithaca \& London: Cornell University Press.

Jacobs, Keith; Kemeny, Jim; Manzi, Tony (1999), "The Struggle to Define Homelessness: A Constructivist Approach," in Susan Hutson \& David Clapham (eds.), Homelessness: Public Policies and Private Troubles. London: Cassell, 11-28.

Latour, Bruno (1987), Science in Action. How to Follow Scientists and Engineers Through Society. Cambridge, MA: Harvard University Press.

Law, John (2004), After Method. Mess in Social Science Research. London \& New York: Routledge.

Lyon-Callo, Vincent (2008), Inequality, Poverty, and Neoliberal Governance: Activist Ethnography in the Homeless Sheltering Industry. Toronto: University of Toronto Press [orig. ed.: 2004].

Mol, Annemarie (2002), The Body Multiple: Ontology in Medical Practice. Durham \& London: Duke University Press.

O'Sullivan, Eoin (2008), "Pathways Through Homelessness: Theoretical Constructions and Policy Implications," in Joe Doherty \& Bill Egar (eds.), In My Caravan, I Feel Like Superman: Essays in Honour of Henk Meert 1963-2006. St Andrews: University of St Andrews \& FEANTSA, 71-100.

Pais, José Machado (2006), "A minha casa é um mundo: os sem-abrigo," in José Machado Pais, Nos rastos da solidão: deambulações sociológicas. Porto: Âmbar, 31-72.

Pichon, Pascale (1996), "Survivre la nuit et le jour. La préservation de soi face au circuit d'assistance," Politix, 34(9): 164-179.

Pichon, Pascale (2002), "Vivre sans domicile fixe: l'épreuve de l'habitat précaire," Communications, 73, 11-29.

Rullac, Stéphane (2012), Et si les SDF n'étaient pas des exclus? Essai ethnologique pour une définition positive. Paris: L'Harmattan [orig. ed.: 2005].

Santos, Boaventura de Sousa (2006), "Uma sociologia das ausências e uma sociologia das emergências," in Boaventura de Sousa Santos, A gramática do tempo: para uma nova cultura política. Porto: Afrontamento, 87-125.

Santos, Boaventura de Sousa (2007), "Beyond Abyssal Thinking. From Global Lines to Ecologies of Knowledges," Review, 30(1): 45-89.

Scott, James C. (1985), Weapons of the Weak: Everyday Forms of Peasant Resistance. New Haven \& London: Yale University Press.

Scott, James C. (1990), Domination and the Arts of Resistance: Hidden Transcripts. New Haven \& London: Yale University Press.

Snow, David A.; Anderson, Leon (1993), Down on Their Luck: A Study of Homeless Street People. Berkeley: University of California Press.

Wright, James D.; Rubin, Beth A. (1998), "Les sans-domicile aux États-Unis: leçons tirées de quinze années de recherche," Sociétés Contemporaines, 30: 35-66.

Zeneidi-Henry, Djemila (2002), Les SDF et la ville: Géographie du savoir-survivre. Paris: Bréal. 